\title{
4 Pan-Slavism or Imperial Nationalism? The Role of Russia in the Greek-Bulgarian Ecclesiastical Question (1878-1914)
}

The $19^{\text {th }}$ century in southeastern Europe is usually referred to as the age of nationalism. As has already been said, the traditional Ottoman millet system, in which religious communions existed inside the dominant Muslim state, was replaced step by step by independent national states. Serbia, Greece, Romania, Montenegro and Bulgaria appeared on the map of Europe during the $19^{\text {th }}$ century. The armed struggle of these nations followed a preliminary period of awakening of national consciousness. The historical memory of the medieval kingdoms of Serbia and Bulgaria and the Byzantine Empire contributed to this process. For the Greeks the more recent memory of Byzantium fanned by the Patriarchate of Constantinople, and their dominant position among the Orthodox populations of the empire paved the way for nationalism. Inspired by the ideals of the French Revolution and romantic European philhellenism, as well as by the material resources of the Greek diaspora in Russia, this historical memory developed into the Great idea (Megali idea), i.e., uniting all Greek lands into one kingdom. The revolution of 1821 and the formation of an independent Greek state was the first step in that direction. ${ }^{243}$

The situation with the Bulgarians was different. Up to 1393 the Patriarchate of Tyrnovo was the spiritual centre for Bulgarians. During the Ottoman period, the Archbishop of Ohrid was the head of the Bulgarian people, but in 1767 his seat was subsumed under that of the Patriarchate of Constantinople. ${ }^{244}$ The national self-consciousness of the Bulgarian people was by the end of the $18^{\text {th }}$ century in decline; the Bulgarian language was used in remote areas only, while the townspeople readily adopted the Greek language and culture. After the publishing of Istorija Slavenobulgarskaja (The History of the Bulgarian Slavs) by Monk Paisii, the nationalistic revival of the Bulgarian people began. ${ }^{245}$ Bulgarian nationalism was to a great extent

\footnotetext{
243 G. P. Henderson, The Revival of the Greek Thought 1620-1830 (Edinbourgh, 1971); D. Dakin, The Greek Struggle for Independence. 1821-1833 (Berkley and L. Angeles, 1973); Modern Greece: Nationalism and Nationality (Athens, 1990); L. Sergeant, Greece in the Nineteenth Century: A Record of the Hellenic Emancipation and Progress: 1821-1897 (London, 2002); O. E. Petrunina, Grecheskaja nacija i gosudarstvo $v$ XVIII-XX vv. (Moscow, 2010).

244 Ju. Trifonov, "Unishtozhavaneto na tyrnovskata patriarshija i zameniavaneto i s avtonomno mitropolitstvo-archiepiskopstvo," Sbornik za narodni umotvorenija, nauka i knizhnina 22-23 (19061907): 1-40; I. Snegarov, "Unishtozhenijto na Ochridskata patriarchija i vlijanijeto na elinizyma v Bulgarija”, Makedonski Pregled 3 (1926).

245 Paisij Hilendarski. Slavianobulgarska Istorija (Sofia, 1973).
} 
imported from Russia where Slavophilic romanticism spread in the 1830 s and 40s. ${ }^{246}$ The first phase of Bulgarian nationalism (growing awareness of the historical roots of the Bulgarian nation) lasted for the duration of the 1830s and 40s. This was followed by the second phase (1850s and 60s), in which nationalism spread by professional agitators. The second stage was soon replaced by the third one, a mass nationalistic movement. ${ }^{247}$ The peculiarity of Balkan nationalism was its close connection with the church hierarchy. The religiously-oriented millet system as the only legitimate form of autonomy in the Ottoman Empire provided the groundwork for political independence; church organization and church autonomy served as a model of future political organization. In this process the Bulgarians had two major opponents-the Greek Patriarchate of Constantinople and the Ottoman government. The nationalist movement, ecclesiastical in its form, was purely national and political in its content. Orthodoxy was used by the Bulgarian political elite as a means to gain other pragmatic goals. $^{248}$

As the reforms of the Tanzimat (after 1856) did not bring the Bulgarian leadership the results they expected, the most radical wing began to take more overt action. In 1860, the Bulgarian Metropolitan Ilarion for the first time did not mention the patriarch in the Easter liturgy in the Bulgarian church in Constantinople. This was commonly perceived as an open declaration of disobedience. ${ }^{249}$ Indeed, from then on, all the Bulgarian provinces stopped paying their fees to the patriarchate. Greek bishops were no longer recognized as church principals in many places. The final stage of the conflict was the establishment of the autonomous Bulgarian church in 1870, approval having been received from the Ottoman government. In 1872 the Patriarch of Constantinople called a council of the heads of the Eastern Orthodox churches at which the Bulgarians were condemned as heretics. This is known as the Bulgarian Schism. The development of the conflict prior to 1872 is closely aligned with the Bulgarian movement for national liberation..$^{250}$

246 A. Smith, Nations and Nationalism (London, 1998). Here one can observe an interesting modification of the formation of an "Imagined Community" (following B. Anderson, Imagined Communities. Reflections on the Origin and Spread of Nationalism (London, N.Y., 2006)). The national idea was imported to the south Slavs and especially the Bulgarians in two ways-immediately from Western Europe by European intellectuals, and via the Russian Slavophile movement, which also had European (German) roots. 247 M. Hroch, Social Preconditions of National Revival in Europe: A Comparative Analysis of the Social Composition of Patriotic Groups among Smaller European Nations (Cambridge, 1985).

248 This kind of nationalism, different from that in western Europe, developed in pre-industrial societies and was not connected with disappointment in religion as a basis of life: E. Kedourie, Nationalism (London, 1960): 6, M. Hroch, Social Preconditions of National Revival; A. Smith, Nations and Nationalism: 109-113. Here the main thesis of E. Gellner's construction about the connection between capitalism and the rise of nationality does not work (E. Gellner, Nations and Nationalism (Oxford, 1983)).

249 T. Zhechev, Bylgarskijat Velikden ili strastite bylgarski (Sofia, 1975).

250 V. Teplov, Greko-bolgarskij vopros po neizdannym istochnikam (St. Petersburg, 1889), 35; V. F. Kurganov, “Istoricheskij ocherk greko-bolgarskoj raspri,” Pravoslavnyj Sobesednik (1873): 187-260; I. F. Maka- 
The Greek-Bulgarian ecclesiastical schism remained one of the key problems in the political life of the Balkans from the second half of the $19^{\text {th }}$ till the beginning of the $20^{\text {th }}$ century. The decision of the Constantinople Council of 1872 put Russia in a very difficult position. On the eve of the war against Turkey, 1877-1878, Russia could not turn away from the Bulgarians who were its main ally in the Balkans. Yet Russia could not break off its relations with the Ecumenical Patriarchate, the most influential church in the Orthodox East. That is why the Russian government chose to keep silent and to avoid any official statements as suggested by the Metropolitan of Moscow, Filaret Drozdov. Nevertheless, the Schism was the main obstacle for Russia in implementing its desired policy in the Balkans. Using ecclesiastical affairs to shape its policy in the Middle East had always been an effective strategy for Russia, but the Bulgarian Schism paralyzed Russia's ability to advance its interests in gaining control of Constantinople and the Straits. As a result, all the efforts of Russian diplomacy in the next decades were directed towards mending the Schism. ${ }^{251}$

The war of 1877-1878 created a new state in the Balkans-the Bulgarian Principality. But hundreds of thousands of Bulgarians continued to live in areas controlled by the Ottoman Empire. In most places the Bulgarian population were mixed with Greek, Serb, Turk and Valach. Because of these mixed populations the Ottoman provinces in Europe, primarily Macedonia and Thrace, remained ripe for potential revolts and disorder. The leaders of the most volatile nations-the Greeks and the Bulgarianssupposed that an ecclesiastical division of Macedonia between the patriarchate and the Bulgarian exarchate would anticipate a parallel political division. To this end, the leaders of the Greek kingdom and the Bulgarian government focused their attention on spreading propaganda among their citizens to shore up support. Initially for the Greeks, this was carried out by the Greek metropolitans and educators, supported by Greek consulates. ${ }^{252}$ The Bulgarians attempted to restore their ecclesiastical system in Macedonia, which had been destroyed by the war. In 1878 a new exarch was nomi-

rova, Bolgary i Tanzimat (Moscow, 2011), 121-228; See the bibliography in the most recent book: V. Boneva, Bylgarskoto nacionalnoosvoboditelno dvizhenie 1856-1870 (Sofia, 2010). On the proclaiming of the Schism and the role of the Russian embassy up to 1877 see: Z. Markova, Bylgarskata Ekzarhija 1870-1879 (Sofia, 1989), 251; Cyril patriarch Bylgarski, Graf N. P. Ignatiev i Bylgarskijat cyrkoven vypros. Izsledvane i dokumenti (Sofia, 1958), 114-126; V. Boneva, Bylgarskoto nacionalnoosvoboditelno dvizhenije, 1028-1058; D. A. Stamatopoulos, “The Bulgarian Schism Revisited”, Modern Greek Studies Yearbook 24/25 (2008-2009), 105-125. 251 Ev. Kofos, “Attempts at mending the Greek-Bulgarian Ecclesiastical Schism (1875-1902),” Balkan Studies (1984), no. 2: 347-375.

252 D. Dakin, The Greek Struggle in Macedonia, 1897-1913 (Thessaloniki, 1966); N. Danova, Nacionalnijat vypros v gryckite politicheski program prez XIX vek (Sofia, 1980); F. Adanir, "The Socio-Economic Environment of Balkan Nationalism: the Case of Ottoman Macedonia 1856-1912” in: H. G. Haupt, M. Muller and S. Woolf, eds., Regional and National Identities in Europe in the XIX ${ }^{\text {th }}$ and $X X^{\text {th }}$ centuries (Boston, 1998): 221-254; B. Gounaris, “Social Cleavages and National “Awakening” in Ottoman Macedonia”, East European Quarterly 29 (1995) 4: 409-427; R. S. Peckham, “Map Mania: Nationalism and the Politics of Place in Greece, 1870-1922”, Political Geography 19 (2000) 1: 7-95. 
nated to Constantinople, Iosif Bobchev. He devoted 35 years of his life to the realization of Bulgarian interests in Macedonia. His main goal was to have the Ottoman government issue berats for the Bulgarian bishops of the province which would secure their positions, and to create a sustainable and effective system of Bulgarian national schools, which were considered to be the main ideological weapon in nationalistic propaganda. Bulgarians hoped that all Macedonian Slavs would, one region after another, join the Bulgarian exarchate. ${ }^{253}$

Throughout his reign, Patriarch Joachim III (first term 1878-1884) maintained a moderate pro-Russian position. His ideal of a supra-national Ecumenical Patriarchate was supported by the Russian embassy, but was met with strong opposition from the Greek government. ${ }^{254}$ The first tension to develop after the war had to do with Bulgarian and Russian priests serving the Eucharist together in the territories occupied by the Russians (the concelebration). The patriarch warned the Russian embassy that he would prohibit Greek priests from having ecclesiastical relations with Russian priests who concelebrated with Bulgarian clergy. This position put Ambassador LobanovRostovskii in a difficult position:

It is the first time since this regrettable Greek-Bulgarian conflict that our clergy is called to openly interfere in this affair. Up to now we managed to keep the role of peacemaker and serve as an intermediary between the competing claims of the Greeks and Bulgarians. ${ }^{255}$

An official of the embassy, Onou, was in charge of the negotiations regarding this matter. Despite reconciliatory talks with the patriarch, Onou held a rather pessimistic view:

The Bulgarians are preoccupied with their national interests. The Bulgarian hierarchy is not held in high regard by the Bulgarians, it has no traditions independent of Constantinople, and it is not interested in reconciling with the patriarchate, especially given the changing circumstances and the fact that after the last war [the Russo-Turkish War] the Bulgarian church, is de facto, recognized by our hierarchy. ${ }^{256}$

The official answer of the Russian Synod was very pointed. It stressed that the Council of Constantinople in 1872 involved only the Greek church of the Ottoman Empire, so its decisions were not binding for the Russian church. Moreover, the accused party,

253 A. Arnaudov, Exarch Iosif i bylgarskata kulturna borba sled syzdavaneto na Ekzarchijata (18701915), I (Sofia, 1940); Cyril patriarch Bylgarski, Bylgarskata ekzarchija v Odrinsko i Makedonija sled osvoboditelnata voina 1877-1878, t. I, 1878-1885, kn, 2 (Sofia, 1970); Chr. Temelski, ed., Bylgarski Ekzarh Iosif I. Dnevnik (Sofia, 1992).

254 Chr. Kardaras, I politiki drasi tou patriarchi Ioakeim G' (Proti patriarchia 1878-1884) (Ioannina, 1993); idem, Ioakeim G'-Char. Trikoupis. I antiparathesi. Apo tin anekdoti allilografia tou Oikoumenikou Patriarchi (1878-1884) (Athens, 1998).

255 Dispatch of Lobanov, December 25, 1878, RGIA, f. 797, op. 48: 2otd. 3 st., 11. 13-14v.

256 M. K. Onou-to T. I. Filippov, December 17, 1878, GARF, f. 1099, op. 1, d. 2323, 1l. $5^{\mathrm{v}}$-6. 
the Bulgarians, was not invited to the session of the Council, and the resolution had been signed under pressure. The Russian Synod rejected the main argument of the Greeks, the charge that Bulgarians were guilty of the heresy of philetism, i.e. ethnic distinction. In 1833 when the Greeks of the Greek kingdom had proclaimed an independent church they had not been accused of any heresy. Therefore the Russian Synod refused to prohibit its priests from concelebrating with Bulgarian priests. ${ }^{257}$ A preliminary document was sent to the ambassador, but it looks like the definitive document was never given to the patriarch; according to the additional instruction Lobanov received, he could do with it as he pleased.

The relations of the Russian embassy and the exarchate in the period 1879-1885 were rather tense. The Russians insisted on mending the divide; as a first step, Russia insisted that the Bulgarian church had to be contained within the borders of the principality. The patriarchate shared this position. "The appointments to the episcopal sees in Macedonia is one of the main reasons that a peaceful solution to the GreekBulgarian conflict remains unattainable, which is so undesirable for us", Ambassador Novikov wrote in $1880 .{ }^{258}$ In his further dispatches Novikov stressed that the gulf between the patriarchate and the exarchate widened every day.

The next Russian ambassador to Constantinople, A. I. Nelidov, maintained the same policy. In 1883 he advised the exarch not make stringent demands on the patriarch, and added that if the patriarchate required the Russian Synod to take an official position it would not side with the Bulgarians. ${ }^{259}$

In Macedonia, where the situation was tense and the anti-Bulgarian activities of the Greek population growing, Russian diplomacy worked to calm both sides without favouring either. Russian policy was to maintain the status quo in Macedonia. This stance was reflected in a private document written for the Holy Synod in 1883. Its author stressed that the prevalence of political aspirations in Bulgaria led to the situation that most people regarded the church as a mere political tool; Greek clergy also held this view and were supported by Greek bankers and politicians. The western Powers, he wrote, were interested in inciting hostility, because they support Catholic and Protestant efforts to direct its propaganda at the Orthodox population. Therefore, the author of the note continued, Russia could not remain an indifferent spectator; it had to keep to its traditional course in foreign affairs. It could not afford to alienate the Ecumenical Patriarchate which was still the stronghold of the Greeks. At the same time Russia was not able to abandon the Bulgarians. The best chance for reconciliation was if the Athenian government would mediate, according to Russia. The author proposed the follow-

257 Extract from the resolution of the Holy Synod, February 22/March 2, 1879, RGIA, f. 797, op. 48, 2 otd. 3 st., d. 156, 1l. 39-42v.

258 RGIA, f. 797, op. 50, 2 otd. 3 st., d. 131, 1l. 6-6". See also: Nacionalno-osvoboditelnoto dvizhenie na macedonskite i trakijskite bylgari 1878-1944 (Sofia, 1994), 121-123.

259 Chr. Temelski, ed., Bylgarski Exarch Iosif I. Dnevnik, 115. 
ing plan: the Bulgarians were to send delegates to the patriarch asking for pardon; the ecclesiastical borders would be determined on an ethnographic basis-the eparchies of Pelagonia, Melnik, Ochrid, Skopje, Strumnica, Moglen, Veles and Poliana were to create a separate district, independent from Constantinople, as 1,002,700 Bulgarians lived there and only 2,218 Greeks; the bishops in this district would be elected by the population and one or two of them would have a seat in the Patriarchal Synod. ${ }^{260}$ Of course this proposal was doomed as it did not satisfy the main demand of the Bulgarians, namely, the ecclesiastical integration of Macedonia and the eparchies of the principality, which Bulgaria insisted had to precede political union.

During the struggle to preserve the rights and privileges of the church in the Ottoman Empire from 1883-1884, the Greek clergy in Macedonia organized anti-Bulgarian demonstrations meant to demonstrate their loyalty to the Ottoman government. Based on the reports of the Russian consul to Thessaloniki, A. Jakobson, the embassy sent a communique to the patriarchate asking for an explanation of the anti-Bulgarian demonstrations. In its reply, the Ecumenical Church stated that the disorder was the result of Bulgarian nationalists acting on the instigation of agents of the Roman Pope. ${ }^{261}$ Russian diplomats were frightened by the prospect of growing Bulgarian sympathies for union with Rome. Wishing to maintain an equilibrium in Macedonia the ambassador worked to have berats issued for the Bulgarian bishops in the area. Russia in the 1880 s preferred not to support either side as a secret instruction sent to the new consul to Thessaloniki, Iastrebov, in 1886 makes evident: "We must ensure that the opportunity to use the assistance of all the different elements which are gathered in Macedonia remains and to lean on them only because each of them can be useful for our own political aims". ${ }^{262}$ It may be that these words provide the best explanation for the national or pan-Slavic orientation of the Russian policy in the Balkan region in the $19^{\text {th }}$ century.

During the time leading up to the complete cessation of relations between Russia and Bulgaria in 1886, the tone of the Russian embassy dealing with the exarch changed. ${ }^{263}$ Now Nelidov advised Iosif to leave Constantinople for Sofia. In these difficult circumstances, given the ingratitude of the 'bratushki' (i.e. the Bulgarians), some politicians in Russia insisted that diplomacy had been short-sighted in challenging the patriarchate and working towards the establishment of an independent Bulgarian church. The author of a note dated June 10,1887, called for full support of the Greek clergy in order to ensure its assistance "in the moment of our inevitable collision with pan-Hellenism on the ruins of the Turkish domination". ${ }^{264}$ A number of articles criti-

260 AVPRI, f. 340, op. 801, d. 25, 11. 3-10v․

261 AVPRI, f. Embassy in Constantinople, op. 517/2, d. 2921, 1l. 1-2v , 14-15"

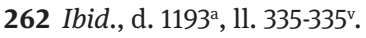

263 On this period see: V. Kosik, Vremya razryva: politika Rossii v bolgarskom voprose, 1886-1894 gg. (Moscow, 1993).

264 AVPRI, f. Embassy in Constantinople, op. 517/2, d. 2923, 11. 12-14. 
cizing the policy of Ignatiev were published in the newspaper Grazhdanin in 1888. Replying to these accusations, Ignatiev explained that it was the Congress of Berlin in 1878 and the policy of Austro-Hungary that led to the failure of Russian policy. After political boundaries are determined, the ecclesiastical problems will immediately be solved, he wrote. ${ }^{265}$ The further actions of the Russian embassy in 1889-1890 can be explained by current events. The official note of the prime minister of the Bulgarian government, S. Stambolov, to the Ottoman porte demanding that the rights of the Bulgarians in Macedonia (June 4, 1890) be maintained did not receive the support of Russia. As a result of Stambolov's note, two berats for the Bulgarian metropolitans of Skopje and Ochrid were issued the same year. The Russian embassy decided to demonstrate its disapproval to the Bulgarians by supporting the patriarchate in its struggle against the Ottoman government to preserve the rights of the church and by supporting the appointment of Serbs to bishoprics in Macedonia. In this critical moment Russia demonstrated its support of the patriarchate. Russia maintained the same course of diplomacy during the next two years, 1891-1892. ${ }^{266}$

The restoration of relations between Russia and Bulgaria in 1895 and the coming to power of K. Stoilov began a new period in Bulgaria's policy regarding Macedonia. Stoilov devised a plan in which the exarchate would obtain less territory than that provided for in the San Stefano Treaty of 1877, but the patriarchate had to recognize that the exarchate must be contained within the borders of the Bulgarian Principality. However, Stoilov's efforts failed because they did not receive the approval of Prince Ferdinand. Hoping to gain popularity among his people, he proposed that all of Macedonia be Bulgarian. But both Greek and Bulgarian extremists wanted to possess all of Macedonia and so it was evident that the problem could not be solved peacefully.

In the 1890s the tension in Macedonia reached new heights as Bulgarian (chetnici) and Greek (andartes) guerilla groups began armed opposition. Both sides continued to struggle for the ecclesiastical self-determination of the population. Such a struggle created additional problems for Russia which had just signed a treaty with Austro-Hungary to preserve the status quo in Macedonia (1897); it was not prepared to enter into another war in the Balkans. The Bulgarian exarch, Iosif, was also very anxious about the armed movement because it seriously hindered his plan of a stepby-step peaceful resolution. Moreover, afraid to lose Russian support in this matter, he was obliged to take seriously the repeated concerns of the Russian embassy.

The approval of this election by the sublime porte took place because of the vigorous support of the Russian embassy. The Russian embassy maintained close relations with Joachim III during the years after his resignation in 1884 and hoped that he would

265 N. P. Ignatiev-to N. K. Giers, in: M. N. Pokrovskii, ed., K. P. Pobedonostsev i ego correspondenty, Pis'ma i zapiski I, 2 (Moscow, 1923): 854-857.

266 Chr. Temelski, ed., Bylgarski Exarch Iosif I. Dnevnik, 316. 
continue his supranational policy in ecclesiastical affairs. ${ }^{267}$ Nevertheless, in the new political environment of the early $20^{\text {th }}$ century, Joachim could not and did not want to protect the Bulgarians. Russia's response to Joachim's stance is well documented in the official replies of the Russian Holy Synod to the two messages that Joachim sent to autocephalous churches in 1902 and 1904. In answer to the second letter the Russian Synod expressed its displeasure with and even irritation at the growth of nationalism and its negative consequences for ecclesiastical affairs. During the deliberations on how to respond, the representative of the Ecumenical Patriarch in Moscow, Archimandrite Iacobos, sent a note to Metropolitan Antonius of St. Petersburg detailing the suffering of the Greek population of Macedonia and Thrace at the hands of the tyrannical Bulgarian chetniks. In the message, Archimandrite Iacobos quoted a Greek bishop of these dioceses who described the violence and robbery of the chetniks and how they forced the peasants to convert to the exarchate. He also devoted a special section to describing the activities of the Russian gendarmerie who kept track of the developments of the Mürzsteg program. In a letter, Metropolitan Stefan wrote that the Russian officers, on coming to Voden, did not visit the Greek prelate but went directly to the Ottoman administrator of the region accompanied by a Bulgarian in order to avoid being accused of supporting either the Greeks or the Bulgarians. In the villages of Mesimerion and Vladovon, Russian officers also encouraged the exarchists and supported the activities of the Bulgarian guerillas. ${ }^{268}$ The patriarch, using Stefan's account of the Russian officers, appealed to the Russian Synod which greatly irritated the Russian ministry of foreign affairs and did nothing to contribute to the rapprochement of the Russian and Ecumenical churches. The correspondent of Moskovskije vedomosti commented in this way:

The Russian Orthodox officers are educated and well informed enough to know that the Greek patriarchal and exarchate churches are two churches equally Orthodox in the canonical and theological senses. That is why a Russian Orthodox officer would never take the side of either hierarchy; even less would Russian officers consider it decent to support openly the intrigues of the Bulgarian revolutionary organization. ${ }^{269}$

Another concelebration of Russian and Bulgarian clergy took place in 1902 at the consecration of the Russian Memorial Church in Shipka. The rite was celebrated by the

267 See the diplomatic correspondence of I. A. Zinoviev in the period of the elections: RGIA, f. 797, op. 71,2 otd. 3 st., d. 133.

268 Archimandrite Iacob to Metropolitan Antonii, July 1, 1904. RGIA, f. 797, op. 84, 2 otd., 3 st., d. 365, 11. 5-8. Similar complaints were directed against the Russian officers by the Serbs. They wrote that while visiting the village Doriane the officers settled in a Bulgarian house (Moskovskije vedomosti, no. 251 (September 11, 1904)).

269 Petrus, “A new phase of the Macedonian question”, Moskovskije vedomosti, December 5 (18), 1904, No. 336; December 7 (20), No. 338; December 8 (21), No. 339. This commentary is an interesting example of neglecting the Bulgarian schism by an official pan-Slavic newspaper. 
Metropolitan of Stara Zagora Methodii, and the Russian prior of the military clergy, Zhelobkovsky. Both Russian and Bulgarian clergy were present as was Grand Duke Nikolai Nikolayevich and the Bulgarian Prince. The concelebration was important for the Bulgarian exarch as a demonstration of the Orthodoxy of the Bulgarian church. In his conversation with the Russian ambassador, Iosif stressed that the church should be consecrated by representatives of both parties. Zinoviev replied that Russia had never regarded the Bulgarian church as schismatic and that the concelebration had his blessing. However, he insisted that it be kept from the Greeks up to the last moment. ${ }^{270}$ Metropolitan Symeon of Varna, and members of the Bulgarian Synod and the Bulgarian minister of finance, Sarafov also discussed the concelebration. Symeon was unwilling to accept the invitation to be present at the ceremony without also concelebrating. ${ }^{271}$ As the Patriarchal Synod was unaware of the preparations for the ceremony, the matter was discussed there only after the event. In its session on October 1, 1902 a telegram from the Metropolitan of Philippopolis was read which described the Russian-Bulgarian concelebration. The Metropolitan of Xanthi demanded immediate action against the Russian clerics according the decision of the Synod of 1872, but Joachim III, afraid of open conflict with Russia proposed that the decision be postponed. The decision was again postponed at the next session of the Synod on October 24, 1902. The Metropolitan of Efessos thought that a note should be sent to the Russian Holy Synod protesting the concelebration, but also added "of course we cannot undertake vigorous measures against the Russian church", by which he meant breaking off canonical relations between the Russian and the Constantinople churches. He also argued that this measure was unsuitable due to the "difficult circumstances in which the church finds itself at the present moment”. The efforts of the patriarch to discuss the matter with the ambassador also failed as Zinoviev stated that Prior Zhelobkovskii was a military priest and hence not under the jurisdiction of the Russian Synod. ${ }^{272}$ Though the question was not brought up in any future sessions of the Synod, the patriarch's hesitation to deal with the concelebration of the Russian and Bulgarian clerics was a major issue during the patriarchal crisis of $1904{ }^{273}$

One of the main ways in which Russia refused to acknowledge the Schism was its support for Bulgarian churches and monasteries. For example, in 1903 the nuns of the Batoshevsky Monastery near Sevlievo requested assistance from the Russian Holy Synod for the building of a church. The Russian ambassador in Sofia supported this application and stressed that it would be advantageous as it would strengthen the Orthodox presence in the district of Sevlievo, especially in light of the active mis-

270 Chr. Temelski, ed., Bylgarski Exarch Iosif I. Dnevnik, 506.

271 M. K. Sarafov-to metropolitan Symeon, August 29, 1902. Archive of the Bulgarian Academy of Sciences, f. 144k, op. 1, d. 677, 11. 1-1"v.

272 Report of the Patriarch to the Synod on November 19.

273 "Peri ton en Shipka eorton", Ekklesiastiki Alitheia (1904) Parartima, 3-4. 
sionary work of Protestants and Catholics in the region. The Russian Synod decided to send a thousand rubles to the monastery from the reserves of the Bessarabian capital in acknowledgement of the presence of Bulgarian monasteries in Bessarabia affiliated with the Mt. Athos real estates.

The Greek-Bulgarian conflict became extremely tense in 1906 after a series of Greek massacres in Bulgaria. ${ }^{274}$ The conflict began when the inhabitants of Varna refused to recognize the new Greek metropolitan. Soon the disorder spread to other cities and towns. After the second unsuccessful attempt of the prelate to land in Varna, the patriarch sent a series of notes to the sublime porte in which he called the actions of the Bulgarians "incompatible with the principles of religion, morality and civilization”. The Bulgarians, he wrote, tried to take possession of the Greek church and Greek hospital in Varna. ${ }^{275}$ In his subsequent reports to the porte, the patriarch presented information about the statistics of the Greek population in Bulgaria ${ }^{276}$ and demanded the removal of the "schismatic" exarchate from Constantinople and the Bulgarian bishops from the Macedonian and Thracian eparchies, and the closing of the Bulgarian Church of St. Stephan in Constantinople and the Bulgarian seminary in Pera. ${ }^{277}$ Shortly thereafter Joachim addressed a memorandum to the ambassadors of all the Great Powers in Constantinople in which he reported on the occupation and plunder of the Greek churches in Varna, Kavarna, Philippoplis, Stenimachos, Tatarpazardzik, Peristera, Rushtuk and Pyrgos and about the fire and massacre in Anchialo on July $30 .{ }^{278}$ On August 14 the patriarch sent a communiqué to the Russian embassy informing the Russian government about these events. ${ }^{279}$ However, Russia

274 See a detailed report about these events in the newspaper Ekklesiastiki Alitheia and in: Sp. Sfetas, "Oi anthellinikoi diogmoi stin Anatoliki Romylia kata to etos 1906 sta plasia tis boulgarikis kratikis politikis”, Balkanika Symmeikta, (1993-1994), 5-6: 75-91; M. Christemova, “Antigryckoto dvizhenie v Asenovgrad prez 1906 g.” Godishnik na istoricheskija muzej v Plovdiv (2004) 2: 102-113; Ju. Konstantinova, "The anti-Greek movement in Bulgaria (1906) in the perception of the Bulgarian political elite", Etudes Balkaniques. (2009) 3; V. Traikova, “Oshte za antigryckite pogromi v Bylgarija prez 1906 g.”, Istoricheski pregled (2010) 5-6: 151-162. The pretext of the massacre was the murder of the inhabitants of the village Zagoricheni by Greek armed groups.

275 Protests of Joachim III to the Minister of Justice sent on July 3/15, 8/21, 12/25, 1906)

276 In the takrir of July 13/26, 1906 one can find the following information. In the territory of Bulgaria about 100,000 people belong to the Patriarchate in five districts (Varna, Mecembria, Anchialo, Sozoagathoupolis, Philippopolis). There are 159 priests, 125 churches and monasteries, 66 schools (7,744 pupils) and 125 teachers. According to Bulgarian statistics in 1905 from 64,000 to 70,000 Greeks lived in Bulgaria. See: H. Silianov, Osvoboditelnite borbi na Macedonia, 2. Sled ilindenskoto vyzstanie (Sofia, 1943), 254.

277 Takrirs of July 13/26 and July 28/August 10, 1906

278 The texts of these protests were collected and edited in Constantinople the same year: Memorandums addresses aux représentants des grandes puissances à Constantinople et autres documents relatifs aux récents évènements de Bulgarie et de Roumélie Orientale. (Constantinople, 1906), 5-6, 7-8, 9, 10-12, 13, 14-15-the takrirs to the Ottoman government; 25-34-the text of the memorandum to the Great Powers. See also: AVPRI, f. Embassy in Constantinople, op. 517/2, d. 2940.

279 Ibid., 11. 9-10. 
remained neutral and did not respond to the protests of the patriarch. The Russian press also remained silent on the events in Bulgaria. The church-political magazine, Kolokol, found the patriarch's memorandum to the Great Powers sharp in tone and damaging to the Bulgarians and the Bulgarian government. ${ }^{280}$ Moskovskije vedomosti quoted a passage from the inquiry made by the minister of internal affairs, Petkov, saying that the catastrophe in Anchialo was provoked by the Greeks who opened fire on a Bulgarian anti-Greek meeting. According the report of the minister, the number of Greek victims had been fantastically exaggerated by the Greeks. ${ }^{281}$

The only Russian official who expressed sympathy to the Greeks was Professor I. I. Sokolov of St. Petersburg Theological Academy. He published a number of articles in support of the Greeks and the patriarchate on the pages of Tserkovnye vedomosti. Sokolov was a true advocate of the idea of an Ecumenical pan-Orthodox union in the spirit of Byzantinism. According to him, the main instigators of the present events were the Ottoman government and the European concert. The Russian embassy was also responsible for the conflict as it had approved the reforms of the patriarchate and had initiated the establishment of the Bulgarian exarchate. ${ }^{282}$ From 1900 to the 1910 s Sokolov was one of the few representatives of philhellenism in Russian public life and ecclesiastical circles. The governmental circles preferred to remain uninvolved in the events in the Near East and the Balkans. The official church press reflected the nationalistic pan-Orthodox position. Thus, in his article in the journal of the Holy Synod Tserkovnye vedomosti, the canonist, S. V. Troitskii wrote, "the last collision between the patriarchate and the exarchate makes us wish for a more vigorous interference on the part of the Russian church in the affairs of the Eastern Orthodox churches". ${ }^{283}$

The Bulgarian Schism changed the direction of Russian policy in the East and turned it from a policy of political romanticism into a policy of Russian national exclusiveness. Before the Schism, the Eastern Question was regarded as an obviously Russian one; the Schism estranged both the Greeks and the Bulgarians from the Russians. One author wrote:

The passion for nationalism in Russia increased this estrangement. The Eastern churches due to their constant discord were seen to be in continual tension with each other while the Russian church which has no internal tensions, was seen to be quite stable with no need to step out of its isolation. Now the epoch of narrow nationalism is coming to an end and Russia needs direct and close contacts with the Eastern churches. ${ }^{284}$

280 Kolokol, October 17, 1906, no. 223.

281 Moskovskije vedomosti, August 8, 1906, no. 195.

282 [I. I. Sokolov], “Sovremennoje polozhenije ellinisma”, Tserkovnyj vestrik, August 17 (1906), no. 33: 1085-1088.

283 S. Troitskii, "Meroprijatija Vselenskoj patriarchii protiv bolgarskogo ekzarcha," Tserkovnije vedomosti, (1908), Pribavlenija, no. 5: 236-238.

284 Ibid. 
By 1910 the negotiations to mend the Bulgarian Schism were deadlocked and as one could see, the relations between the two sides worsened. A new stage began with the negotiations to establish the Balkan League. In mid-1910 Austria sought to bring about a rapprochement between Romania and Turkey in order to counter Greece and Bulgaria. Patriarch Joachim requested the Russian embassy to identify all the documents concerning the proclamation of the Schism and the attempts to mend it undertaken in the 1870s. As a starting point for the reconciliation, Joachim put forward a plan developed by Onou in 1873 and 1874. The Bulgarians put forward the only condition preserving the firman of 1870: now that they have officially appointed bishops to seven sees in Macedonia, it might be possible, in their opinion, for the negotiations to move forward. ${ }^{285}$ The position of the embassy, however, remained the same. Ambassador Charykov stressed that at least officially the Russian embassy had to remain uninvolved in these negotiations. Nevertheless, Russia could not help but support this movement which should strengthen the alliance of the Balkan states against the expansion of Austro-German ambitions and the Turkish attempts of pan-Ottoman denationalization.

The next step in ecclesiastical reconciliation was made in Sofia by the Greek ambassador, Panas. The Bulgarian prime minister, Malinov invited the exarch to begin negotiations with the patriarchate, but Iosif was not inclined to hurry. In November 1910 the Bulgarian deputy from Bitola openly expressed his approval of reconciliation in the Ottoman parliament. ${ }^{286}$ But further action was blocked by members of the Patriarchal Synod. Because the involvement of the Greek government was essential to move the agenda forward, the Russian ambassador in Athens, A. Sverbeev, was instructed to continue negotiations regarding the mending of the Schism. But Greek political leaders did not comply. Minister of Foreign Affairs Griparis persuaded Sverbeev that the Greek government had no influence on the Synod of Constantinople. The truth of the matter was that the Greek government was not interested in reconciliation because the continuation of the Schism suited the Greek national struggle in Macedonia. ${ }^{287}$ The mood in Sofia was the same. The secretary of the Synod of the Bulgarian Church, Kostov, told the Russian ambassador in Sofia, Urusov, that

we don't see any benefits for the exarchate: our strength was born in struggle and we need further struggle for its final establishment ... The history of the last ten centuries proves that the Bulgarians and Greeks have never understood each other and of course will never in the future. ${ }^{288}$

285 Dispatches of the Russian ambassador N. V. Charykov, August 1/14, 1910 no. 114 and October 27/ November 9, 1910, no. 140. AVPRI, f. Embassy in Constantinople, op. 517/2, d. 3471, 11. 76-78v.

286 Tserkovnyj vestnik, no. 48 (1910): 1513-1516.

287 Dispatch of N. V. Charykov, November 10/23, 1910, no. 157. AVPRI, f. Embassy in Constantinople, op. 517/2, d. 3471, 11. 63-65; Telegram of A. Sverbeev, November 13/26, 1910. Ibid., 1. 60; Dispatch of N. V. Charykov, November 17/30, 1910. Ibid., 1l. 56-58v.

288 L. V. Urusov to S. D. Sazonov, December 2, 1910, ibid. 11. 48-50v. 
The Bulgarians are self-confident and aggressive, accused Urusov. Being low church believers, they use the Schism and the situation of the moment to their own political end. The Bulgarian ambassador in Athens, Hadji Mishev, also acknowledged that Bulgaria was not interested in mending the Schism:

From an ecclesiastical point of view, the mending of the Schism, which is not recognized by any of the Balkan states and especially by Russia, is not of great importance for Bulgaria. From a political point of view, of course, it would contribute to the peaceful coexistence of the Bulgarian and Greek elements in Macedonia. Nevertheless, Greece is against the reconciliation because it would lead to rapprochement of the Bulgarians-Exarchists and the Slavophones-Patriarchists. ${ }^{289}$

The idea of a reconciliation also met with resistance, albeit not openly expressed, in Serbia, which had always supported the Greeks in Macedonia and now was afraid it would find itself isolated. ${ }^{290}$

The ongoing negotiations demonstrated once more that ecclesiastical reconciliation required not only a political alliance but also a division of power between the competing states in Macedonia, Greece, Bulgaria and to a lesser extent, Serbia. Exarch Iosif was ready to abandon the idea of a Greater Bulgaria but he could not accept the Greek Great idea of a revived Byzantium with a continuous coastline from Greece to Constantinople. ${ }^{291}$

After arriving in Constantinople, the new Russian ambassador, Giers, continued the negotiations. He visited both the patriarch and the Bulgarian exarch. Joachim III told him that the patriarchate did not object to mending the Schism but insisted on observing the church canons and some other conditions. ${ }^{292}$ The meeting with the exarch was much more cordial and mutually beneficial. As Iosif noted in his diary, the Russian ambassador had initiated a visit with him (a sign of respect in the eyes of the exarch), while the previous ambassadors only returned his visits. Iosif complained about the decreasing Bulgarian population in Macedonia-about 200,000 of them had left the province during the previous few decades. Working to mend the Schism was rather difficult for him as he was obliged to assist those communities that wanted to join the exarchate. In every case the patriarchate would insist on the removal of the exarchate from Constantinople to Sofia. Iosif could not accept this because in Constantinople he could advocate for Bulgarians and support the Bulgarian cause. ${ }^{293}$

In contrast to the prevailing skepticism among Bulgarian politicians, the Metropolitan of Varna, Symeon, regarded the mending of the Schism as a necessary step for

289 A. Sverbeev to S. D. Sazonov, January 2, 1911, no. 1. Ibid., 11. 40-41.

290 Dispatch of Gartwig from Belgrade, November 21, 1910. AVPRI, f. Embassy in Constantinople, op. 517/2, d. 3471, 11. 53-54.

291 P. K. Mishev to I. St. Geshov, November 26, 1911. CDA, f. 322k, op. 1, d. 269, 1l. 80-81.

292 Alexandropoulos to the Greek Ministry of Foreign Affairs. April 28, 1912. AYE, f. 21, 1, 1.

293 Chr. Temelski, ed., Bylgarski Ezarch Iosif I. Dnevnik, May 3, 1912: 778. 
the Bulgarian church. According to his proposal, reconciliation should be followed by a proclamation that the Bulgarian church would be autocephalous. This act would enhance relations with Russia and its church and would return the Bulgarian people to the Orthodox fold. Only with the restoration of normal relations with the Russian church would the Bulgarian clergy be able to resist Catholic and Protestant propaganda in the country, he told Nekliudov, the Russian ambassador in Sofia. ${ }^{294}$ in his commentary on this conversation, Nekliudov noted that in his opinion Russia had to be more accepting of the declarations and applications of the Bulgarian clergy.

The successful actions of the Bulgarian army in October 1912 and the real possibility that it would soon enter Constantinople again raised the question of mending the Schism. Who would celebrate the first liturgy in St. Sofia? This question worried both the Greeks and the Bulgarians. At this critical time several sessions of the Patriarchal Synod were held. As a compromise, the Greek metropolitans agreed to ignore the Schism, but only temporarily and only in Constantinople in order for a concelebration to take place, presided over by the patriarch with the exarch. ${ }^{295}$ The exarch, for his part, demonstrated his readiness to formally ask for pardon from the patriarch. Nevertheless, the plans of the Bulgarian government were not realized due to Russia's opposition as it was unwilling to allow any country to enter Constantinople and to control the Straits. If Ferdinand decided to enter Constantinople, he would see all of Europe turn against himself demanding him to change course, the Russian ambassador told the exarch. ${ }^{296}$ The preservation of the sovereignty of Turkey in Constantinople, the Straits and the adjoining territory was one of Russia's demands. Immediate action in the region became a matter of discussion at several sessions of the Russian Council of Ministers near the end of November 1912. Advocates of the war such as the minister of war, V. A. Suhomlinov, and the Grand Duke Nikolai Nikolayevich among others accused the minister of foreign affairs, Sazonov, of unnecessary hesitations. However the voices in favour of caution were vindicated. ${ }^{297}$ After the retreat of the Bulgarian army from Chataldji the question of the Schism was no more a matter of serious discussion.

The new political situation after the Balkan Wars created significant problems for the patriarchate because it lost most of its prosperous eparchies in Macedonia. At a session of the Patriarchal Synod, the metropolitans said that though perpetuating the Bulgarian Schism suited Greek interests, after the resolution of the Eastern Question and the division of Macedonia, the autocephaly of the Bulgarian church would be proclaimed. Then the exarch would leave Constantinople and the patriarchate would be

294 Dispatch of Nekliudov, 10 August, 1912. RGIA, f. 797, op. 82, 2 otd. 3 st., d. 441, 1l. 2-3.

295 Kanellopoulos to the Greek Ministry of Foreign Affairs. September 9, 1912. AYE, f. 83, 3.

296 AVPRI, f. Embassy in Constantinople, op. 517/2, d. 3464, 11. 50.

297 See: Ju. A. Pisarev, “Rossia i mezhdunarodnyj krizis v period pervoj balkanskoj voiny (oktiabr' 1912-maj 1913 g.)”, Istorija SSSR (1986) 4: 56-67. 
obliged to end the Schism. ${ }^{298}$ The defeat of Bulgaria in the Second Balkan War really changed the situation. After the Treaty of Bucharest (August 30, 1913) and the establishment of new borders in the Balkans, ecclesiastical divisions were to be in accord with political borders. The exarch's cause in Macedonia was lost and in November 1913 he was forced to leave Constantinople. The problem of the Schism continued to worry Russia. After the departure of Iosif it seemed that the obstacles to reconciliation were removed. But diplomats failed to take into account the extreme national tension following the defeat of Bulgaria. The Russian embassy tried to exert pressure on the patriarch regarding the critical financial and political position of the Orthodox church in Turkey in the first half of 1914. Talking with Patriarch Germanos V, Giers offered him help on the condition that the Schism be mended. Fonvisin, a staff of the Russian embassy carried out the preliminary negotiations in Sofia. ${ }^{299}$ The final attempt on the part of Russia before it entered the First World War was to discuss the terms of reconciliation with Exarch Iosif during his visit to the Russian ambassador to Sofia, Savinskii. It was supposed that Professor I. S. Palmov of St. Petersburg Theological Academy would draft the official letter to the Ecumenical Patriarchate outlining the terms of a settlement. ${ }^{300}$ The war interrupted the negotiations and the letter was never sent. In 1915 the exarch made a final attempt: he asked the Russian priest in Athens to start negotiations with E. Venizelos, the Greek prime minister to mend the Schism. ${ }^{301}$ Although official negotiations ended when Turkey entered the First World War, in 1917 the Metropolitan of Cyprus, Meletios Metaksakis, still wanted to raise the matter of the Bulgarian Schism at the Synod in Moscow. ${ }^{302}$

The Greek-Bulgarian ecclesiastical question vividly demonstrates the character of the Russian policy in the Balkan region at the end of the $19^{\text {th }}$ and beginning of the $20^{\text {th }}$ centuries. Delaying action and maintaining the status quo together with other political difficulties led to the temporary cessation of Russian diplomatic efforts in the Near East. Constantly maneuvering between the Greeks and the Bulgarians did not enhance Russia's authority in the region; neither could it temper nationalistic opposition in the Balkans. The Bulgarian Schism was resolved only in 1945 when the political borders were finally determined, and population exchange took place. As a result there were no more regions with mixed populations and no reasons for further conflict.

298 Kannelopoulos-to L. Koromilas, Reports of February 7 and 9, 1913. AYE, f. 53, 5.

299 AVPRI, f. Embassy in Constantinople, op. 517/2, d. 3464: 52-55.

300 Chr Temelski, ed., Bylgarski Exarch Iosif I. Dnevnik, 811.

301 Ibid., 819.

302 Vatibelas (Larnaka)-to the Greek Foreign Ministry, October 2/15, 1917. AYE, B/35, f. Panrossiko Synedrio Moshas, 1917. 